Molecules 2008, 13, 267-271

\title{
molecules
}

ISSN 1420-3049

(C) 2008 by MDPI

www.mdpi.org/molecules

Communication

\section{Two New Constituents from Artemisia capillaris Thunb.}

Hong-Yu Ma ${ }^{1}$, Yi Sun ${ }^{1}$, Yu-Zhi Zhou ${ }^{1}$, Min Hong ${ }^{2}$ and Yue-Hu Pei ${ }^{1, *}$

${ }^{1}$ School of Traditional Chinese Materia Medica, Shenyang Pharmaceutical University; Shenyang 110016, P.R. China

${ }^{2}$ National Standard Laboratory for Chinese Medicine, Nanjing University of Chinese Medicine, Nanjing, P.R. China

* Author to whom correspondence should be addressed; E-mail: peiyueh@vip.163.com; Tel.: +86-2423986483

Received: 26 November 2007; in revised form: 2 February 2008 / Accepted: 4 February 2008 / Published: 5 February 2008

\begin{abstract}
Two new compounds, 6'-O-caffeoyl- $p$-hydroxyacetophenone-4- $O$ - $\beta$-D-glucopyranoside (1) and 6-amino-9-[1-(3,4-dihydroxyphenyl)ethyl]-9H-purine (2) were isolated from the aerial parts of Artemisia capillaris Thunb. The structures were established on the basis of spectral data.
\end{abstract}

Keywords: Artemisia capillaris; p-hydroxyacetophenone; adenine

\section{Introduction}

Infusions of the buds, stems and leaves of Artemisia capillaris (Yin Chen Hao, Capillary or Oriental Wormwood) have been used in Chinese Traditional Medicine since antiquity as a cholagogic, antipyretic, anti-inflammatory and diuretic purposes and in the treatment of jaundice [1-6]. Coumarins, flavonol glycosides and a group of unidentified aglycones have been reported so far from the inflorescence of Artemisia capillaris [7,8]. Our investigation of the aerial parts of this plant has led to the isolation of two new constituents. This paper deals with the isolation and structural determination of these compounds. 


\section{Results and Discussion}

Compound 1, a yellow powder, was formulated as $\mathrm{C}_{23} \mathrm{H}_{24} \mathrm{O}_{10}$ on the basis of HR-FAB-MS data $\left(\mathrm{m} / \mathrm{z}\right.$ 461.1436, $[\mathrm{M}+\mathrm{H}]^{+}$, calcd. 461.1446). Its ${ }^{1} \mathrm{H}-\mathrm{NMR}$ spectrum indicated one methyl $(\delta 2.38, \mathrm{~s})$, a 1,4-disubstituted benzene ring [ $\delta 7.85(2 \mathrm{H}, \mathrm{d}, J=8.7 \mathrm{~Hz})$ and $\delta 7.10(2 \mathrm{H}, \mathrm{d}, J=8.7 \mathrm{~Hz})]$ and a 1,2,4trisubstituted benzene ring [ $\delta 6.76(1 \mathrm{H}, \mathrm{d}, J=8.1 \mathrm{~Hz}), \delta 6.96(1 \mathrm{H}, \mathrm{d}, J=8.1 \mathrm{~Hz})$ and $\delta 7.05(1 \mathrm{H}, \mathrm{s})]$. In addition, the coupling constants of the proton signals at $\delta 7.46$ and $\delta 6.25$ were $15.8 \mathrm{~Hz}$, indicating the presence of two trans-olefinic protons. Thus, it was presumed that $\mathbf{1}$ contained an $O$-caffeoyl group $[9,10]$. The ${ }^{1} \mathrm{H}-\mathrm{NMR}$ and ${ }^{13} \mathrm{C}-\mathrm{NMR}$ spectra also indicated the presence of a glucopyranosyl unit $\left[\delta_{\mathrm{H}}\right.$ 5.07 (anomeric proton), $\left.\delta_{\mathrm{C}} 99.6,76.4,74.0,73.2,70.1,63.3\right]$. The coupling constant of the anomeric proton signal $(J=9.0 \mathrm{~Hz})$ indicated the $\beta$-configuration of the glucose. Long-range correlations were observed in the heteronuclear multiple-bond connectivity (HMBC) spectrum as follows: (a) $\delta_{\mathrm{H}} 7.05$ and $\delta_{\mathrm{C}}$ olefinic carbon $145.8, \delta_{\mathrm{H}} 6.96$ and $\delta_{\mathrm{C}} 145.8, \delta_{\mathrm{H}} 7.46$ and ester carbonyl carbon $\delta_{\mathrm{C}} 166.4$ which further evidenced the presence of $O$-caffeoyl group; (b) methyl proton at $\delta_{\mathrm{H}} 2.30$ and $\delta_{\mathrm{C}} 196.4, \delta_{\mathrm{H}} 2.30$ and 130.9 indicating that the methyl and 1,4-disubstituted benzene ring was connected by a carbonyl carbon [4]; (c) anomeric proton of glucose $\delta_{\mathrm{H}} 5.07$ and $\delta_{\mathrm{C}} 160.9$, H-6' of glucose and ester carbonyl carbon $\delta_{\mathrm{C}} 166.4$ showed that the $O$-caffeoyl group and 1,4-disubstituted benzene ring must be linked at the position $\mathrm{C}-6^{\prime}$ and $\mathrm{C}-\mathbf{1}^{\prime}$ of the glucose, respectively. Acid hydrolysis of $\mathbf{1}$ furnished the sugar component, which was confirmed as glucose by TLC comparison with an authentic sample. Thus, compound 1 was established to be 6'-O-caffeoyl-p-hydroxyacetophenone-4-O- $\beta$-D-glucopyranoside (Figure 1).

Figure 1. Important HMBC correlations of $\mathbf{1}$.

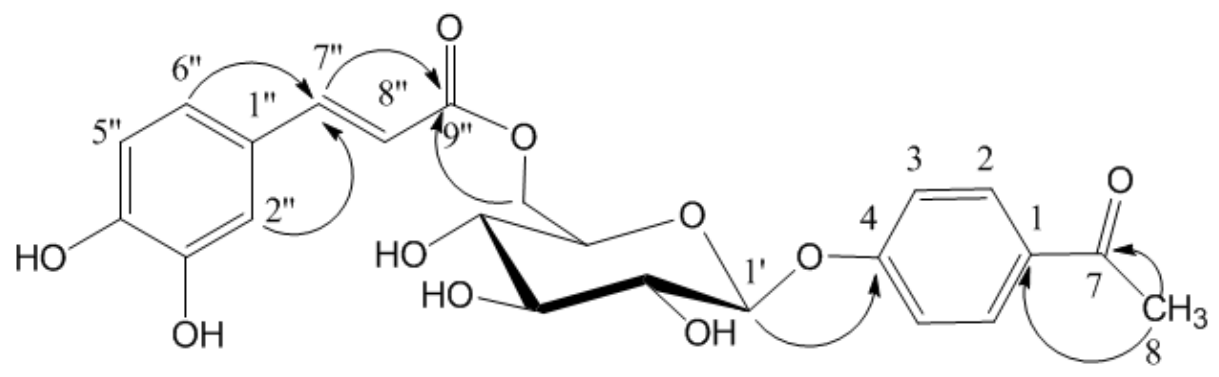

Compound 2 was obtained as an amorphous powder. The molecular formula was established to be $\mathrm{C}_{13} \mathrm{H}_{13} \mathrm{~N}_{5} \mathrm{O}_{2}$ based on HR-FAB-MS data (m/z 272.1136, $[\mathrm{M}+\mathrm{H}]^{+}$, calcd for $\mathrm{C}_{13} \mathrm{H}_{14} \mathrm{~N}_{5} \mathrm{O}_{2}$ : 272.1128). The signals in the ${ }^{1} \mathrm{H}-\mathrm{NMR}$ spectrum of compound 2 at $\delta 8.27$ (s), 8.11 (s) and $7.19\left(2 \mathrm{H}, \mathrm{s}, \mathrm{NH}_{2}\right)$ along with those in the ${ }^{13} \mathrm{C}-\mathrm{NMR}$ spectrum at $\delta 118.9,139.2,149.2,152.4$ and 156.0 indicated the presence of an adenine ring. The ${ }^{1} \mathrm{H}-\mathrm{NMR}$ spectrum also showed a 1,2,4-trisubstituted benzene ring $[\delta 6.67,1 \mathrm{H}$, $\mathrm{d}, J=8.4 \mathrm{~Hz}), \delta 6.64(1 \mathrm{H}, \mathrm{d}, J=8.4 \mathrm{~Hz})$ and $\delta 6.69(1 \mathrm{H}, \mathrm{s})]$ and a methyl which was connected to a methine [ $\delta 1.85$, d, $J=7.2 \mathrm{~Hz}$ ), $\delta 5.64$ (q, $J=7.2 \mathrm{~Hz}$ ). In its HMBC spectrum long-range correlations were observed between $\delta_{\mathrm{H}} 5.64$ and $\delta_{\mathrm{C}} 139.2$ and $\delta_{\mathrm{H}} 5.64$ and $\delta_{\mathrm{C}} 114.0$, indicating that both the adenine ring and benzene ring were connected to the methine. In summary, based on HSQC and HMBC spectral data, compound 2 was determined to be 6-amino-9-[1-(3,4-dihydroxyphenyl)ethyl]-9H-purine (Figure 2). 
Figure 2. Important HMBC correlations of 2.

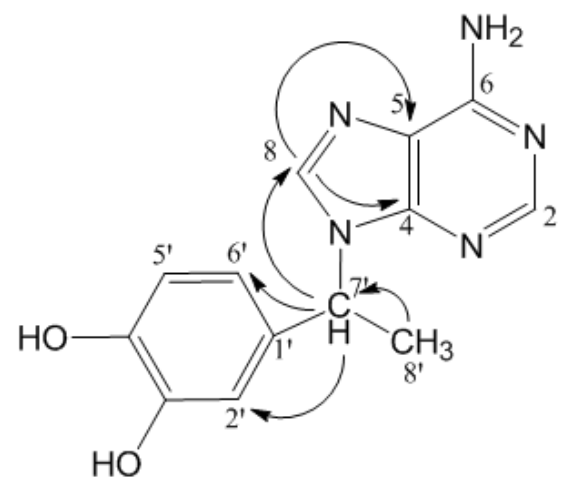

\section{Experimental}

\section{General}

The NMR data were obtained on a Bruker ARX-300 spectrometer (300 MHz for ${ }^{1} \mathrm{H}$ and $75 \mathrm{MHz}$ for ${ }^{13} \mathrm{C}$ ) in DMSO-d6 with TMS as internal standard. The HR-FAB-MS data were obtained on the Micross Mass Autospec-UltimaE TOF mass spectrophotometer. Chromatography was performed on silica gel (200-300 mesh), Sephadex LH-20 and with a Shimadzu LC-8A HPLC instrument equipped with a reversed-phase column.

\section{Plant material}

The material investigated were aerial parts of A. capillaris purchased from the Cooperative of Traditional Chinese Medicine of Shenyang, P.R. China. A voucher specimen was identified by Prof. Qi-Shi Sun and deposited at the School of Traditional Chinese Medicine of Shenyang Pharmaceutical University, P.R.China.

\section{Extraction, isolation and product characterization}

The dry aerial parts (10 kg) of A. capillaries were extracted with boiling water three times, and then precipitated with $75 \%$ aqueous alcohol. After evaporation of the solvents under reduced pressure, the residue $\left(1.1 \mathrm{~kg}\right.$ ) was suspended in $\mathrm{H}_{2} \mathrm{O}$ and extracted sequentially with petroleum ether, ethyl acetate and $n$-butanol. The ethyl acetate extract (53 g) was subjected to silica gel CC with elution by $\mathrm{CHCl}_{3}-\mathrm{CH}_{3} \mathrm{OH}$ in increasing polarity to obtain eight fractions (A to $\mathrm{G}$ ). Fraction $\mathrm{F}$ was then purified by Sephadex LH-20 column chromatography eluted with $\mathrm{CH}_{3} \mathrm{OH}$, and further separated by preparative RP-HPLC eluted with $35 \%$ aqueous $\mathrm{CH}_{3} \mathrm{OH}$ to give compounds 1 (20 mg) and $2(8 \mathrm{mg}) .{ }^{1} \mathrm{H}$ - and ${ }^{13} \mathrm{C}$ NMR data are shown in Table 1. 
Table 1. NMR data of compounds 1, 2 (ppm from TMS, in DMSO- $d_{6}$ ).

\begin{tabular}{|c|c|c|c|c|}
\hline \multirow{2}{*}{ Position } & \multicolumn{2}{|l|}{1} & \multicolumn{2}{|l|}{2} \\
\hline & $\mathbf{H}$ & C & $\mathbf{H}$ & C \\
\hline 1 & & 130.9 & & \\
\hline 2 & $7.84(\mathrm{~d}, J=8.7 \mathrm{~Hz})$ & 130.2 & $8.11(\mathrm{~s})$ & 152.4 \\
\hline 3 & $7.10(\mathrm{~d}, J=8.7 \mathrm{~Hz})$ & 116.0 & & \\
\hline 4 & & 160.9 & & 149.2 \\
\hline 5 & $7.10(\mathrm{~d}, J=8.7 \mathrm{~Hz})$ & 116.0 & & 118.9 \\
\hline 6 & $7.84(\mathrm{~d}, J=8.7 \mathrm{~Hz})$ & 130.2 & & 156.0 \\
\hline 7 & & 196.4 & & \\
\hline 8 & $2.38(\mathrm{~s})$ & 26.3 & 8.27 (s) & 139.2 \\
\hline $1^{\prime}$ & $5.07(\mathrm{~d}, J=9.0 \mathrm{~Hz})$ & 99.6 & & 132.5 \\
\hline $2^{\prime}$ & $3.30(\mathrm{~m})$ & 73.2 & $6.69(\mathrm{~s})$ & 114.0 \\
\hline $3^{\prime}$ & $3.32(\mathrm{~m})$ & 76.4 & & 145.2 \\
\hline $4^{\prime}$ & $3.20(\mathrm{~m})$ & 70.1 & & 149.2 \\
\hline $5^{\prime}$ & $3.70(\mathrm{~m})$ & 74.0 & $6.67(\mathrm{~d}, J=8.4 \mathrm{~Hz})$ & 115.3 \\
\hline $6^{\prime}$ & $\begin{array}{l}\text { 4.41(d, } J=11 \mathrm{~Hz}) \\
4.17(\mathrm{dd}, J=11,7.3 \mathrm{~Hz})\end{array}$ & 63.3 & $6.64(\mathrm{~d}, J=8.4 \mathrm{~Hz})$ & 117.0 \\
\hline $7^{\prime}$ & & & $5.64(\mathrm{q}, J=7.2 \mathrm{~Hz})$ & 52.0 \\
\hline $8^{\prime}$ & & & $1.85(\mathrm{~d}, J=7.2 \mathrm{~Hz})$ & 20.6 \\
\hline $1^{\prime \prime}$ & & 125.0 & & \\
\hline $2^{\prime \prime}$ & $7.05(\mathrm{~s})$ & 114.1 & & \\
\hline $3^{\prime \prime}$ & & 145.2 & & \\
\hline $4^{\prime \prime}$ & & 148.8 & & \\
\hline $5^{\prime \prime}$ & $6.76(\mathrm{~d}, J=8.1 \mathrm{~Hz})$ & 115.2 & & \\
\hline $6^{\prime \prime}$ & $6.96(\mathrm{~d}, J=8.1 \mathrm{~Hz})$ & 121.0 & & \\
\hline $7 "$ & $7.46(\mathrm{~d}, J=15.8 \mathrm{~Hz})$ & 145.8 & & \\
\hline $8^{\prime \prime}$ & $6.25(\mathrm{~d}, J=15.8 \mathrm{~Hz})$ & 113.0 & & \\
\hline $9 "$ & & 166.4 & & \\
\hline
\end{tabular}

Acid Hydrolysis of $\mathbf{1}$ [12]

Compound 1 (8 mg) was refluxed with 10\% $\mathrm{HCl}$ in $75 \% \mathrm{EtOH}(3 \mathrm{~mL}$ ) for $6 \mathrm{~h}$. After cooling, the reaction mixture was extracted with EtOAc $(3 \mathrm{ml})$. The water layers were concentrated and compared with $D$-glucose by TLC analysis [system 1: silica-gel, $n$-BuOH- $\mathrm{C}_{5} \mathrm{H}_{5} \mathrm{~N}-\mathrm{H}_{2} \mathrm{O}$ (8.0:4.0:3.0), $R f$ : 0.24; system 2: silica-gel, EtOAc-MeOH- $\mathrm{H}_{2} \mathrm{O}-\mathrm{AcOH}$ (6.5:2.0:1.5:1.5), $R f: 0.42$ ]. Those confirmed that the sugar moiety obtained from aqueous acid hydrolysis of compound $\mathbf{1}$ was $D$-glucose.

\section{Acknowledgements}

This work was partly supported by National Natural Science Fund of China (grant No. 30300446) and Jiangsu Natural Science Fund (grant No. 03KJB360094). 


\section{References}

1. Tang, W.; Eisenbrand, G. Chinese Drugs of Plant Origin, Chemistry, Phamacology and use in traditional and modern medicine. Springer Verlag: New York, 1992; p. 179.

2. Han, K.-H.; Jeon, Y.-J.; Athukorala, Y.; Choi, K.-D.; Kim, C.-J.; Cho, J.-K.; Sekikawa, M.; Lee, C.-H. A water extract of Artemisia capillaris prevents 2,2'-azobis(2-amidinopropane) dihydrochloride-induced liver damage in rats. J. Med. Food 2006, 9, 342-347.

3. Han, J.; Zhao, Y.-L.; Shan, Li-M.; Huang, F.-J.; Xiao, X.-H. An experiment on standardized cell culture assay in assessing the activities of Composite Artemisia Capillaris Tablets against hepatitis B virus replication in vitro. Chin. J. Integr. Med. 2005, 11, 54-56.

4. Jang, S.; Kim, Y.-J.; Lee, W.-Y.; Kwak, K. C.; Baek, S. H.; Kwak, G. B.; Yun, Y.-G.; Chai, K.-Y. Scoparone from Artemisia capillaris inhibits the release of inflammatory mediators in RAW 264.7 cells upon stimulation cells by interferon-gamma Plus LPS. Arch. Pharm. Res. 2005, 28, 203-208.

5. Hong, S. H.; Seo, S. H.; Lee, J. H.; Choi, B. T. The aqueous extract from Artemisia capillaris Thunb. inhibits lipopolysaccharide-induced inflammatory response through preventing NFkappaB activation in human hepatoma cell line and rat liver. Int. J. Mol. Med. 2004, 13, 717-720.

6. Hu, Y. Q.; Tan, R. X.; Chu, M. Y.; Zhou, J. Apoptosis in human hepatoma cell line SMMC-7721 induced by water-soluble macromolecular components of Artemisia capillaris Thunberg. Jap. J. Cancer Res.: Gann 2000, 91, 113-117.

7. Yamahara, J.; Kobayashi, G.; Matsuda, H.; Katayama, T.; Fujimura, H. The effect of scoparone, a coumarin derivative isolated from the Chinese crude drug Artemisiae capillaris flos, on the heart. Chem. Pharm. Bull. 1989, 37, 1279-1299.

8. Fakeya, K.; Yoshitomo, N.; Haruji, O. Studies on 'Inchinko' II. Studies on the compounds related to capillarisin and flavonoids. Yakugaku Zasshi 1976, 96, 855-862.

9. Yang, Z. G.; Li, H. R.; Wang, L. Y.; Li, Y. H.; Lu, S. G.; Wen, X. F.; Wang, J.; Akihiro, D.; Susumu, K. Triterpenoids from Hippophae rhamnoides L. and Their Nitric OxideProductionInhibitory and DPPH Radical-Scavenging Activities. Chem. Pharm. Bull. 2007, 55, 15-18.

10. Logendra, S.; Ribnicky, D. M.; Yang, H.; Poulev, A.; Ma, J.; Kennelly, E. J.; Raskin, I. Bioassayguided isolation of aldose reductase inhibitors from Artemisia dracunculus. Phytochemistry 2006, 67, 1539-1546.

11. Shao, Y.; Li, Y. L; Zhou, B. N. Structural elucidation and synthesis of asterbatanoside A from Aster batanfensis. Chin. Chem. Lett. 1994, 5, 675-678.

12. Sun, J.-M.; Yang, J.-S.; Zhang, H. Two New Flavanone Glycosides of Jasminum lanceolarium and Their Anti-oxidant Activities. Chem. Pharm. Bull. 2007, 55, 474-476.

Sample Availability: Available from the authors.

(C) 2008 by MDPI (http://www.mdpi.org). Reproduction is permitted for noncommercial purposes. 